\title{
Awareness and involvement of fathers in care of their under five children in Jorpati, Kathmandu: A cross Sectional Study
}

\section{Poudel S}

Sabitra Poudel, Lecturer, Department of Nursing, Kathmandu Medical College, Kathmandu, Nepal.

\begin{abstract}
Background: Children are not just mini human creatures, they are different entities and have unique need for care, nourishment, play, interaction and harmonious environment. Both parents are equally responsible for providing such environment for optimum growth and development of children. Involvement of fathers in care not only promotes their physical development but also fosters social, cognitive, language and motor development.

Objectives: To assess the awareness and involvement of fathers in care of their under five children.

Methodology: A community based cross sectional study was conducted at Anandanagar tole Gokarneshwar Municipality-8 Jorpati among 128 fathers with children under five years of age. Information was collected through face to face interview using structured questionnaire consisting of statement regarding awareness and involvement in care of their under five years children. Data analysis was done by using statistical package for social science version 16.

Results: Majority (60.1\%) of the fathers had average level of awareness about child care. Regarding involvement, 44.5 $\%$ of the fathers had poor involvement followed by average involvement i.e. $41.4 \%$ in physical care. Around two third (68.9\%) of the fathers showed average involvement in psychological and intellectual developmental activities of their children.

Conclusion: This study shows that though most of the fathers had average awareness regarding childcare, their involvement in the same was less especially in physical care activities.
\end{abstract}

Key words: Awareness; Care of child; Involvement of fathers

DOI: https://doi.org/10.3126/jkmc.v7i4.23316

\section{INTRODUCTION}

C hildren are not just mini human creatures. Children need special care and nourishing in which both parents are equally responsible. For children, their parent's attention and love is superior to anything in the world. The positive, wide-ranging active participation of fathers in their children's life is called father's involvement. It may be manifested over cognitive, affective and behavioral domains ${ }^{1}$. An involved father is one who has sensitive, warm, close, friendly, supportive, intimate, nurturing, affectionate, encouraging, comforting, and accepting relationship with his children. In addition, when child has developed a strong, secure attachment with their fathers, then they are said to be involved ${ }^{1}$.

Though fathers are responsible for more of the breadwinning activities, literature shows that health

Address for correspondence

Sabitra Poudel

Lecturer, B.Sc. Nursing Programme,

Kathmandu Medical College, Duwakot, Bhaktapur

E-mail: sabitrapoude010@gmail.com status of the children improves when both parents take equal responsibilities for proper childcare ${ }^{2}$. Children of involved and loving fathers usually do well in school, pose healthy self-esteem, are more empathetic, exhibit good social behavior, avoid high-risk behaviors such as drug use, truancy and delinquent activity in comparison with children of uninvolved fathers ${ }^{3}$.Quality involvement of father i.e. psychological and emotional perspective during initial days of raising a child, rather than the quantity of direct engagement will have greater impact on positive behavioral outcome in children ${ }^{4}$. There are evidences that the range of positive behavioral outcomes are associated with increment in father's engagement intheir kid's lives ${ }^{5}$. Development of children is influenced both by the quantity and quality of father involvement in their care. Increase in levels of paternal involvement has significant association with highly desirable outcomes for children and families. So for the purpose of fostering increased positive paternal involvement, studies and dissemination of evidence-based knowledge regarding its importance and value is needed. Findings suggest that both parents need to be educated about the fact 
that positive paternal involvement is highly beneficial to children ${ }^{6}$.

In a developing as well as patriarchal country like Nepal, care of under five children is taken as sole responsibility of mother or a woman. Also the literatures on fathers' involvement are very few, hence the present study was carried out to assess the awareness and involvement of fathers in care of their under five children.

\section{METHODOLOGY}

A community based cross-sectional study was conducted among males of Anandanagar tole Gokarneshwar Municipility -8 Jorpati having under-five children. Sample size was calculated on the basis of known awareness percentage i.e. $52 \%$ and the precision was taken as $1 / 5^{\text {th }}$ of prevalence i.e. 0.1 . By using the sample size calculation formula for descriptive cross-sectional study, the calculated sample size was 100 . However, actual sample size was 128 because census sampling technique was used. There were total of 167 households the study site and fathers having at least one underfive children were 137, among them nine were abroad, remaining 128 were interviewed.

Face to face interview was used for data collection after taking informed consent from respondents. The questionnaire consisted of demographic information and questionnaire regarding awareness and involvement. Involvement was divided into two parts: involvement in physical care and involvement in cognitive development i.e. psychological and intellectual developmental activities. For psychological and intellectual activities, fathers with children beyond infancy were only recruited. Content validity of the tool was established with the help of review of literature and expert's consultation. Questionnaire was translated in Nepali for effective communication with respondents. Data were analyzed using Statistical Package for Social Sciences (SPSS) Version 16. Various descriptive statistics were calculated as shown in findings. To assess awareness and involvement, mean score and standard deviation were calculated from the data set. Participants who scored less than 'mean score minus one standard deviation' were categorized as poor; mean score minus one standard deviation'to 'mean score plus one standard deviation' as average, and more than 'mean score plus one standard deviation' as good ${ }^{7}$.

\section{RESULTS}

Of the total 128 respondents, more than half of the respondents (51.6\%) belonged to the age group 30-39 years; $47.7 \%$ had two children; and $53 \%$ of the children were male. Almost half (54\%) belonged to nuclear family and $30 \%$ of the respondents were of Newar ethnicity. Regarding educational status, $29 \%$ of fathers had secondary level of education and same proportion were educated up to bachelor and above; $54 \%$ of respondents were involved in some kind of business while majority i.e. $64.8 \%$ of the mothers were homemakers. Regarding the monthly family income majority $52.3 \%$ were earning between Rs.20,000-50,000 (Table 1).

The study result showed that $60 \%$ of the fathers had average awareness regarding care of under-five children. Regarding their involvement in physical activities of under-five children, $44.5 \%$ the fathers had poor involvement. Talking about involvement in cognitive developmental (psychological and intellectual) activities of their under-five children, $68.9 \%$ of the fathers had average involvement (Table 2.).

\section{Table 1: Socio-demographic profile of the respondents $(n=128)$}

\begin{tabular}{|c|c|c|}
\hline Variables & $\begin{array}{c}\text { Frequency } \\
\text { (n) }\end{array}$ & $\begin{array}{c}\text { Percentage } \\
(\%)\end{array}$ \\
\hline \multicolumn{3}{|l|}{ Age of Father } \\
\hline $20-29$ years & 43 & 33.5 \\
\hline 30-39 years & 66 & 51.6 \\
\hline $40-49$ years & 19 & 14.9 \\
\hline \multicolumn{3}{|l|}{ Mean \pm S.D: $(33 \pm 5.25)$} \\
\hline \multicolumn{3}{|l|}{ No. of Children } \\
\hline 1 & 59 & 46.1 \\
\hline 2 & 61 & 47.7 \\
\hline 3 & 8 & 6.2 \\
\hline \multicolumn{3}{|l|}{ Sex of Child } \\
\hline Male & 68 & 53 \\
\hline Female & 60 & 47 \\
\hline \multicolumn{3}{|l|}{ Type of Family } \\
\hline Nuclear & 69 & 53 \\
\hline Extended/Joint & 59 & 47 \\
\hline \multicolumn{3}{|l|}{ Ethnicity } \\
\hline Brahmin & 36 & 28 \\
\hline Chhetri & 34 & 26.5 \\
\hline Newar & 39 & 30.4 \\
\hline Mongolians & 13 & 10 \\
\hline Other & 6 & 4.6 \\
\hline \multicolumn{3}{|c|}{ Educational Status of Father } \\
\hline Primary & 11 & 8.6 \\
\hline Secondary & 37 & 29 \\
\hline Higher Secondary & 43 & 33.5 \\
\hline Bachelor and above & 37 & 29 \\
\hline \multicolumn{3}{|l|}{ Occupation of Father } \\
\hline Business & 69 & 54 \\
\hline Service & 51 & 39.8 \\
\hline Labour & 8 & 6.2 \\
\hline
\end{tabular}


Table 1 cont ...

\begin{tabular}{lcc}
$\begin{array}{l}\text { Occupation of Mother } \\
\text { Homemaker }\end{array}$ & 83 & 54 \\
Business & 33 & 39.8 \\
Service & 12 & 6.2 \\
Monthly Income & & \\
Less than 25,000 & 5 & 3.9 \\
25,000-50,000 & 67 & 52.3 \\
More than 50,000 & 56 & 43.75 \\
Mean \pm SD: $(51482 \pm 11500)$ & & \\
\hline
\end{tabular}

*SD- Standard Deviation

Table 2: Level of awareness and involvement in care of under-five children $(n=128)$

\begin{tabular}{lcc} 
Level & Frequency (n) & Percentage (\%) \\
Awareness & & \\
Poor & 22 & 17.2 \\
Average & 77 & 60.1 \\
Good & 29 & 22.7 \\
Involvement in & & \\
physical care & & \\
activities & 57 & 44.5 \\
Poor & 53 & 41.4 \\
Average & 18 & 14.1 \\
Good & & \\
Involvement & & \\
in cognitive & & \\
developmental & & 11.3 \\
Activities (n=106) & 12 & 68.9 \\
Poor & 73 & 19.8 \\
Average & & \\
Good & 21 & \\
\hline
\end{tabular}

Mean - S.D.= Poor; Mean-S.D. to Mean+S.D. = Average; Mean + S.D. $=$ Good

*SD- Standard Deviation

\section{DISCUSSION}

Majority (60\%) of the fathers had average awareness regarding care of under five children, $22 \%$ had good awareness and $17 \%$ were having poor awareness. A study conducted in Ramnagar India found that majority (52\%) of the fathers were having good knowledge on care of under five children, (26.5\%) showed average knowledge and only (21.5\%) had poor knowledge?

The study showed that $41.4 \%$ of the fathers had average involvement on physical care activities of children and

\section{REFERENCES}

1. Allen S, Daly K. The effects of Father Involvement in child raising. Father Involvement Research Alliance [Internet]; 2007 [cited 2017 Jun 21]. [Full Text]
$68.9 \%$ of them showed average involvement in cognitive developmental activities. A national health statistics report of United States of America (USA) revealed that $72 \%$ of fathers who were living with their under five years children fed their child or shared meals with them every day, and $81 \%$ of them played with their children daily, which is quite high in comparison with the finding of this study ${ }^{5}$.

The reason behind such result might be our patriarchal cultural influence and stereotypes towards gender role distribution. Similar findings have been obtained from a study done in Botswana i.e. socio cultural factors have negative influence on father's involvement. They concluded that positive reinforcement of male involvement in child care, community sensitization on stereotypical attitude and harmonization of common laws will promote male involvement in child care ${ }^{8}$. Another practitioner review which reviewed 199 articles on father's engagement also revealed seven key barriers in father's involvement which are related to cultural, institutional, professional, operational, content, resource, and policy considerations in their design and delivery ${ }^{9}$. Similarly, a study conducted in New Zealand concluded that there is significant association between father's involvement and child behavior, at the same time, negative child outcomes may be reduced by implementing strategies which promote and enable father's involvement ${ }^{10}$. Findings from another study also suggest that both fathers and mothers need to be educated about the fact that positive paternal involvement keeps children in highly beneficial position ${ }^{6}$.

\section{CONCLUSION}

The overall findings of the study revealed that fathers of under five children have average awareness regarding child care but they were less involved in childcare practices thinking that it is women's responsibility. Hence it is concluded that improvement of knowledge regarding benefits of father's involvement and motivation is needed for fathers to get involved in caring their under five children. Strengthening training regarding male involvement and making people aware that father's involvement have significant positive impact in their children's development will increase the sharing of child rearing responsibilities among both parents.

2. Fogarty K, Evans GD. Being an Involved Father: What Does It Mean?. United States: University of Florida IFAS extension [Internet]. [cited 2017 Jun 21].[Full Text] 
3. Martinez K, Rider F, Cayce N, Forssell S, Poirier J, Hunt $S$ et al. A Guide for Father Involvement in Systems of Care TECHNICAL ASSISTANCE PARTNERSHIP for Child and Family Mental Health. Washington, DC: Technical Assistance Partnership for Child and Family Mental Health [Internet]. 2013 [cited 2017 Jun 21]; [Full Text]

4. Opondo C, Redshaw M, Savage-McGlynn E, Quigley MA. Father involvement in early child-rearing and behavioural outcomes in their pre-adolescent children: evidence from the ALSPAC UK birth cohort. BMJ Open [Internet]. 2016 Nov 22 [cited 2017 Jun 21];6(11):e012034. [DOI]

5. Jones J, Mosher WD. Fathers' involvement with their children: United States, 2006-2010. United States: Natl Health Stat Report [Internet]. 2013 [cited 2017 Jun 21];(71):1-22. [PubMed]

6. Wilson KR, Prior MR. Father involvement and child well-being. J Paediatr Child Health [Internet]. 2011 Jul; 47(7):405-7. [DOI]

7. Karani MH, Angolkar M, Narasannavar AB, Hirachand AD, Sah JK. Assessing the Knowledge, Attitude and Practice Regarding Child Care among the Fathers of Under five Children in Ramnagar Area: A Crosssectional study. Int J InterdiscipMultidiscip Stud [Internet]. 2015 [cited 2017 Jun 21];2(6):113-7. [Full Text]

8. 8. Jorosi-Tshiamo WB, Mogobe KD, Mokotedi MT. Male involvement in child care activities: a review of the literature in Botswana. Afr J Reprod Health [Internet]. 2013 Dec [cited 2017 Jun 21];17(4):35-42. [PubMed]

9. 9. Panter-Brick $C$, Burgess $A$, Eggerman $M$, McAllister F, Pruett K, Leckman JF. Practitioner Review: Engaging fathers - recommendations for a game change in parenting interventions based on a systematic review of the global evidence. J Child Psychol Psychiatry [Internet]. 2014 Nov [cited 2017 Jul 19];55(11):1187-212. [DOI]

10. 10. Tautolo ES, Schluter PJ, Paterson J. Pacific Father Involvement and Early Child Behaviour Outcomes: Findings from the Pacific Islands Families Study. J Child Fam Stud [Internet]. 2015 Dec 11 [cited 2017 Jul 19];24(12):3497-505. [Full Text] 